\title{
Timing of emergence and cave return, and duration of nocturnal activity in an endemic Malagasy fruit bat
}

\author{
Riana V. Ramanantsalama ${ }^{1 *}$ and Steven M. Goodman ${ }^{1,2}$ \\ ${ }^{1}$ Association Vahatra, Antananarivo, Madagascar; ${ }^{2}$ Field Museum of Natural History, Chicago, IL, USA
}

Received for publication: 19 april 2020; Revision received: 18 may 2020;

Accepted for publication: 18 may 2020

\begin{abstract}
Bats emerge from their day roost after dusk and different factors can affect the timing of departure, return, and duration of nocturnal activities. This study provides information on the time of emergence and return of an endemic Malagasy fruit bat, Rousettus madagascariensis, in a cave located in the Réserve Spéciale d'Ankarana, northern Madagascar. Individuals were captured in a narrow passage between the roost and cave exit and capture time for each individual was noted. Variation according to sex, age, and body condition, as well as the influence of season, and the sunset and sunrise time were analyzed. During the dry season, individuals started to emerge at 1913 hours and returned to the cave generally by 0505 hours; the duration of time outside the cave during the dry season was higher in adult females ( 0952 hours) followed by subadult males (0937 hours), sub-adult females (0931 hours), and adult males (0910 hours). During the wet season, individuals exited at 1926 hours and returned at 0351 hours; as in the dry season, adult females spent more time outside the cave ( 0833 hours), than sub-adult females ( 0800 hours), and adult males ( 0752 hours). The period of emergence varied according to the age and sex classes, and time of predawn return associated with the previous nocturnal activity. The period of return was influenced by season, and age and sex classes. Such information is useful to quantify shifts in bat ecology, especially for endemic species with limited distribution or those playing an important role in ecosystem services.
\end{abstract}

Key words: Cave; season; sex; age; Rousettus madagascariensis; Madagascar.

\section{Introduction}

Bats (Chiroptera) are generally nocturnal and using different types of diurnal roost sites such as caves, trees, and anthropogenic structures. It has been hypothesized that nocturnal behavior in bats was evolved to: reduce interspecific competition, specifically with birds, and over food resources (Fleming 1979; Rydell and Speakman 1995); reduce predation (Fenton and Fleming 1976; Erkert 2000); and prevent hyperthermia caused by solar radiation (Speakman et al. 1994; Voigt and Lewanzik 2011). Most bats leave their day roost sites at night to forage and different factors can affect the timing of emergence

\footnotetext{
*Corresponding author. E-mail: rianavaleryb@gmail.com
}

${ }^{\circ}$ Copyright: the Author(s), 2020 | Licensee PAGEPress, Italy 
at night and predawn return. Early research, such as that of Venables (1943) and Erkert (1978), who worked on insectivorous and frugivorous bats of the New World, respectively, were among the first to demonstrate that emergence from roost sites was correlated with sunset time. While this result is intuitive given the life history traits of bats, more than three decades later, their results were supported by Barclay and Jacobs (2011) who examined the emergence of an Old World fruit bat Rousettus aegyptiacus (Geoffroy, 1810) (Pteropodidae) in South Africa. Kunz (1974), McAney and Fairley (1988), Kunz and Anthony (1996), and Lee and McCracken (2001) examined the question with some additional parameters and found that pregnant and lactating female bats left the day roost site earlier in the evening and returned later in the early morning because of higher energetic demands. These studies found that time of emergence and return to day roost sites also varied according to season, age, sex, and depended on the intraspecific variation in a range of ecological parameters. The availability of food is an important component in this relation and Lučan et al. (2016) and Bachorec et al. (2020) have shown a negative correlation between fruit bat home range and food availability. Similar relations have been noted in other groups of mammals, for example, the rodent Octodon degus (Molina, 1782) (Octodontidae), which spent more time outside their burrows foraging during the nonreproductive period because of food scarcity compared to breeding period (Ebensperger and Hurtado 2005).

The period of time bats allocate to being outside the roost is calculable by quantifying the time of emergence and return. Such information is important for the monitoring of bat populations, especially for endemic and threatened species or those performing important ecosystem services, including the regulation of insect pest population size (Altringham 1996; Gonsalves et al. 2013) and seed dispersal (Fleming and Heithaus 1981; Stribna et al. 2019). Precise information associated with emergence and return times have been published for numerous bats species (Vespertilionidae: Pipistrellus pipistrellus (Schreber, 1774), Venables 1943; Swift 1980; Maier 1992; Molossidae: Tadarida brasiliensis (Geoffroy, 1824), Lee and McCracken 2001; Pteropodidae: Cynopterus sphinx (Vahl, 1797), Marimuthu et al. 1998; Rousettus leschenaultii Desmarest, 1820, Vanlalnghaka et al. 2005; R. aegyptiacus, Barclay and Jacobs 2011; Eonycteris spelaea Dobson, 1871, Acharya et al. 2015). While these studies were mainly focused on the influence of age, sex, reproduction state, sunset and sunrise times and moonlight, we further predict that the emergence in the evening and return before dawn also depend on the amount of time an individual bat spent foraging during the previous night and the amount of energy it ingested, as well as its body condition.

On Madagascar, around $80 \%$ of bats are endemic (Goodman and Ramasindrazana 2018) and several authors have shown that the three species of Malagasy fruit bats, all endemic to the island, are important seed dispersers and pollinators of indigenous and endemic plants (e.g. Andriafidison et al. 2006; Andrianaivoarivelo et al. 2011; Vololona et al. 2020). Information on the timing of exit and entrance movements of Malagasy bats are limited to that of Olsson et al. (2006) on insectivorous species, specifically of the family Rhinonycteridae, and no information is available on the island's fruit bat fauna. Members of the widespread Old World genus Rousettus Gray, 1821 usually emerge and return to their cave roost sites once a night (Korine et al. 1994; Andrianaivoarivelo et al. 2011); and the aim of this current study is to determine the time of emergence and return for the endemic Malagasy cave roosting fruit bat, R. madagascariensis Grandidier, 1928. The influence of environmental and intrinsic parameters was analyzed in order to determine variables affecting the emergence and return bouts. 


\section{Materials and methods}

\section{Study area and bat capture}

This study focuses on a population of Rousettus madagascariensis occupying a day roost site in the Grotte des Chauves-souris (12 $\left.57.4^{\prime} \mathrm{S}, 49^{\circ} 7.1^{\prime} \mathrm{E}\right)$, located in the Réserve Spéciale d'Ankarana, extreme northern Madagascar. The local roost site of this species has been estimated in 2015 to shelter around 2000 and 2500 individuals during the dry and wet season, respectively (Noroalintseheno Lalarivoniaina et al. 2017). The dominant vegetation of the protected area is the dry deciduous forest (Goodman et al. 2018) growing on limestone karst and some volcanic intrusions (Cardiff and Befourouack 2008; Goodman et al. 2018). Ankarana has two distinct climatic seasons: 1) a dry season (from May to October), with daily minimum temperatures that can drop to $17^{\circ} \mathrm{C}$ and when most of the woody vegetation in the natural forest drops their leaves; and 2) a wet season (from November to April.), when the daily maximum temperatures can reach $34^{\circ} \mathrm{C}$ and the study area receives approximately $90 \%$ of its annual rainfall; the majority of plants produce fruit during this period (Goodman et al. 2018; Vololona 2020). The field sessions of the current study occurred from 28 August to 5 September 2017 (dry season), and 8 to 13 January 2018 (wet season).

Capture of $R$. madagascariensis during each field session took place once per night, alternatively before dawn (from 0230 to 0545 hours) or after dusk (from 1800 to 2100 hours); a harp trap was placed in a narrow passage between the roosting chamber and cave opening. The precise capture time of each bat was noted and each individual was placed separately in a clean cloth sack and brought back to the camp, some $500 \mathrm{~m}$ from the cave, for processing. Forearm length and weight were recorded for trapped individuals using a ruler and a "Pesola" spring balance, respectively. Further, the sex and reproductive state of each were determined based on the development of external reproductive organs. The age of individuals were ascertained on the state of ossification of the metacarpus and phalange bones of the third or fourth finger using light behind the outstretched wing (Anthony 1988): 1) neonate with no ossification, 2) sub-adult with incomplete ossification, and 3) adult with complete ossification. The physical condition of each animal was evaluated using the body condition index (BCI) i.e. the ratio of body mass to forearm length; with the assumption that heavier individuals would have more energy reserves than lighter individuals of the same size and animals with higher BCI were in good physical condition as compared to those with lower BCI (Speakman and Racey 1986). Individual $R$. madagascariensis were released in the cave within a few hours of capture after being fed ripe banana and sweetened water.

\section{Data analysis}

For the analysis of asymmetrically distributed data (Bullock et al. 1987), the medians of the emergence and return times for each age and sex class were considered; and the influence of environmental (season, sunrise, and sunset time) and intrinsic (age and sex classes, body condition index) parameters were measured. Sunset and sunrise data for the study site were downloaded on timeanddate.com (Cawthen 2014; Wakefield et al. 2015). Given Ankarana's latitude at nearly $13^{\circ} \mathrm{S}$, day length was significantly longer during the wet season as compared to the dry season. In general, the time of emergence and return represented the dependent variables. The independent variables that were a priori selected to influence the time of emergence comprised: season, sunset time, age and sex classes, $\mathrm{BCI}$, and time of return. For the return analysis, the initial independent variables were 
season, sunrise time, age and sex classes, BCI, and emergence time.

Variance Inflation Factor (VIF) was used to detect multicollinearity between independent variables; collinearity between the variables occurs when VIF $>4$ (Gehrt and Chelsvig 2003; García et al. 2015; Ripperger et al. 2015). Independent variables that were not collinear were used in the Generalized Linear Model (GLM) in order to determine those having significant influence on the dependent variables. The Akaike Information Criterion (AIC) of each GLM model was used to select the best performing model i.e. that with the lowest AIC value (Sugiura 1978; Kimura and Waki 2017). The analyses did not include neonates, as they were generally attached to their mother.

\section{Results}

In total, 339 individuals were captured during the two visits to the site. During the dry season, 201 individuals were captured of which $38.8 \%$ were adult males, $21.4 \%$ were subadult males, and 13.9 and $25.9 \%$ were adult and sub-adult females, respectively; no captured female was lactating and $2.0 \%$ of females were pregnant. In the wet season, 138 individuals were captured of which adult and sub-adult males represented 12.2 and 1.4\% of captured individuals, respectively; $82.0 \%$ were adult females, and 3.6\% were sub-adult females; $82.4 \%$ of adult females were lactating and $3.4 \%$ were pregnant.

\section{Time of emergence and return for each age and sex classes}

During the dry season, the median emergence time was 1933 hours or 0157 hours after sunset. The emergence order for the age and sex classes was correlated with the predawn return order on the same day, as sub-adult males, who returned earlier before sunrise, generally emerged earlier with adult females in the evening (at 1913 hours, Figure 1A), followed by sub-adult females (1935 hours), and adult males (2001 hours). The median return time for $R$. madagascariensis during the same season was 0505 hours or 43 minutes before sunrise; sub-adult males generally returned first (0450 hours, Figure 1B), followed by adult females (0505 hours), sub-adult females (0506 hours), and adult males (0511 hours). The mean amount of time spent outside the cave during the dry season for adult females was 0952 hours, while for sub-adult males, sub-adult females, and adult males it was 0937, 0931, and 0910 hours, respectively.

During the wet season, the median emergence time was 1926 hours, 0110 hours after sunset. Some adult females had already left the cave by 1810 hours (Figure 1A), but it was generally adult males who left first (1917 hours), followed by adult females (1927 hours), sub-adult males (1933 hours), and sub-adult females (1937 hours). During the same period, the median return time for $R$. madagascariensis was 0351 hours, or 0135 hours before sunrise. Adult males return earlier (at 0309 hours, Figure 1B) compared to other age and sex classes; sub-adult females entered the cave at 0337 hours, and adult females at 0400 hours. Hence, in the wet season, the adult females left the cave for approximately 0833 hours, 0800 hours for the sub-adult females, and 0752 hours for the adult males. No sub-adult male was captured during the predawn return in the wet season and the time spent outside the cave could not be calculated for this age and sex class.

\section{VIF and GLM results}

For the analysis of independent variables affecting the emergence period, the VIF model that did not present any collinear independent variables was the influence of age and sex 


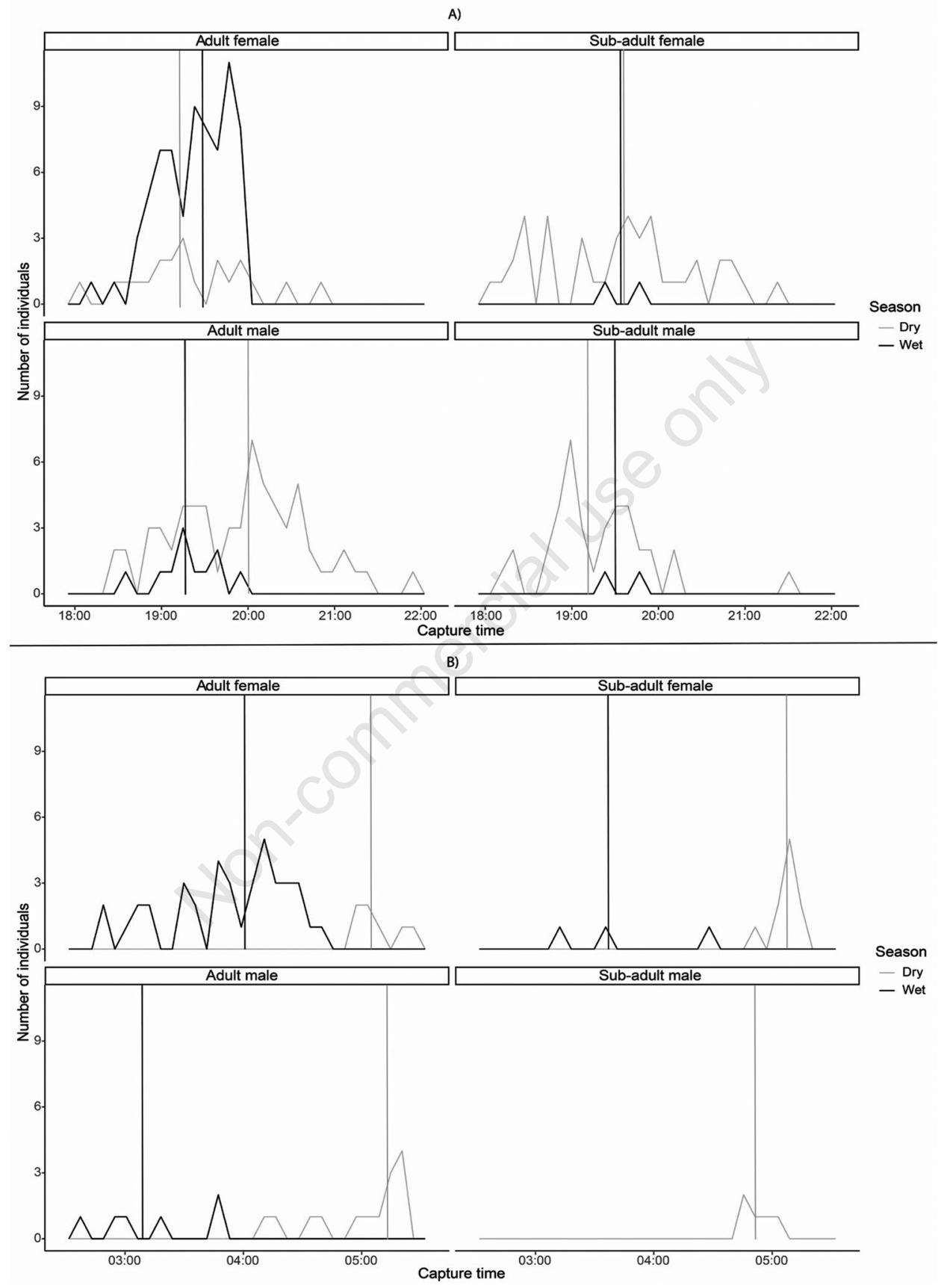

Figure 1. Temporal variation of number of captured Rousettus madagascariensis during their emergence (A) and return (B) from the Grotte des Chauves-souris in Ankarana. The vertical lines inside the graph indicate the medians of the emergence or return time. 
classes, BCI, and time of return (Table 1$)$. The retained GLM model $(A I C=7745.5)$ was the influence of age and sex classes, BCI, and time of return (Table 2); the time of emergence varied significantly according to age and sex classes, and time of return.

For the return analysis, season, age and sex classes, BCI, and emergence time did not show any collinearity (Table 1). The GLM showed that the time of return was significantly influenced by the season, and age and sex classes $(A I C=7081.4$; Table 2$)$.

\section{Discussion}

\section{Comparison between sex and age classes}

For adult $R$. madagascariensis using a cave day roost at Ankarana, the amount of time outside the cave at night for females was higher than males; however, adult males emerged on occasion earlier during the wet season (Figure 1A). According to Korine et al. (1994), adult male $R$. aegyptiacus limit their foraging time during the breeding season, which was presumed to be for territorial defense in the cave; this is a behavior documented for other species of Pteropodidae with harems (Cynopterus sphinx: Balasingh et al. 1995; Campbell 2008; Garg et al. 2018; Balionycteris maculata Matschie, 1899: Hodgkison et al. 2003; Chaverri and Kunz 2010), as well as New World Phyllostomidae bats (Ortega and Arita 2000; Garbino et al. 2018). Adult male R. madagascariensis are more abundant at the Ankarana cave roost site during the dry season, when mating is presumed to occur and thereafter local dispersal takes place to other caves with day roost colonies (Noroalintseheno Lalarivoniaina et al. 2018). However, on the basis of infrared videos of portions of the study colony during the wet season, some adult males were observed mating (Ramanantsalama et al. unpublished data); hence, the shorter period of time foraging for adult males found in this study could be associated with similar inferred behavior to $R$. aegyptiacus and harem defense in the day roost site. To our knowledge, no harem social system has yet been clearly documented in members of the genus Rousettus; and the short proportion of time spent outside the cave for adult male $R$. madagascariensis may also be related to their ability to forage faster as their body size and forearm length are larger than those of the other age and sex classes (Goodman 2011; Andrianaivoarivelo 2012; Goodman et al. 2017).

The difference in time allocated to foraging between adult males and females was more evident during the wet season, during which the majority of adult females were lactating. These females were generally carrying neonates, and with higher energetic demands than non-reproductive females because of constraints associated with carrying neonates and milk production (Gittleman and Thompson 1988; Korine and Arad 1999; Barclay and Jacobs 2011).

Sub-adult males were the second age and sex class, after adult females, spending more time outside the cave during the dry season, followed by sub-adult females. Sub-adult males were observed leaving and returning the cave earlier as compared to other age and sex classes during the dry season (Figure 1). In Indian populations of $R$. leschenaultii, it has been proposed that sub-adults need more time to search for food as compared to adults and emerge earlier from the cave, then return later, but not too late to risk being seen by predatory birds when the dawn light intensity is higher (Vanlalnghaka and Joshi 2005; Vanlalnghaka et al. 2005). Sub-adult $R$. madagascariensis may behave in a similar way as sub-adult R. leschenaultii; and the presence of the barn owl Tyto alba (Scopoli, 1769) (Aves: Strigiformes: Tytonidae), which is a known predator of $R$. madagascariensis on Madagascar (Goodman and Griffiths 2006), could affect their behavior. 


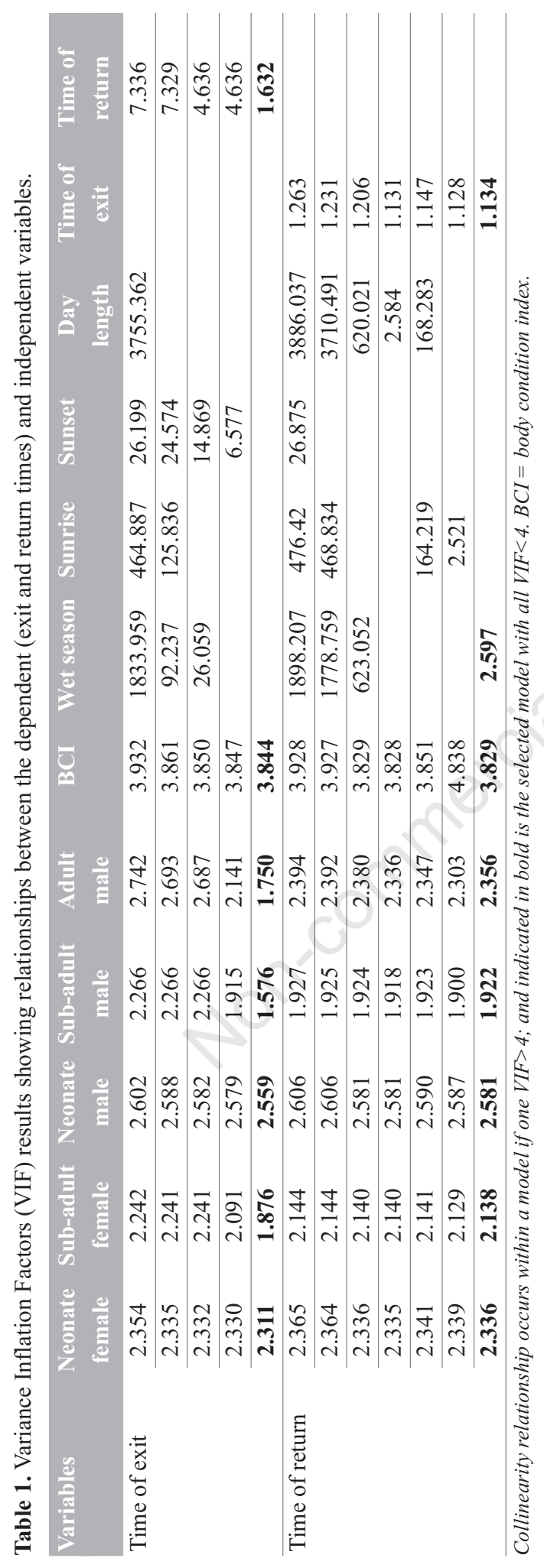




\section{Influence of season}

The present study shows that the amount of time $R$. madagascariensis spent outside the cave is higher during the dry season, when their preferred fruits and flowers are scarcer as compared to the wet season (Vololona 2020; Vololona et al. 2020). Taking into account data presented by Vanlalnghaka and Joshi (2005) and Barclay and Jacobs (2011) on $R$. leschenaultii and R. aegyptiacus, respectively, as well as timing of sunrise and sunset during their field studies (Cawthen 2014; Wakefield et al. 2015), similar seasonal variation was noted in these species, which also have a longer foraging period when food resources are limited. Further, Rousettus might need to travel longer foraging distances when fruits or flowers are scarce as demonstrated for R. aegyptiacus by Lučan et al. (2016).

The wet season in Ankarana is characterized by higher temperatures and rainfall (Goodman et al. 2018; Ramanantsalama et al. 2019) that might impact time spent outside the cave for $R$. madagascariensis, particularly during heavy night showers. Thomas et al. (1991), and Speakman (1995) and Reher et al. (2018) have shown that the risk of hyperthermia in tropical bats, including Pteropodidae, is positively correlated with the ambient temperature. In addition, Pteropodidae have difficulty flying during heavy rains (Korine et al. 1999; Roy et al. 2020), when they might have problems with hypothermia given their limited cold tolerance (Downs et al. 2012). Hence, taking these aspects into account, during the wet season, particularly on nights with heavy or continuous rain, $R$. madagascariensis might be forced to forage for shorter bouts, and probably in the vicinity of the cave. The flip side of these aspects is that this is the period of higher food availability.

\section{Limit of the study}

Information on the seasonal variation of the time of emergence and return for sub-adult R. madagascariensis are still incomplete in this study as only seven sub-adults were captured in the wet season while 95 were caught in the dry season; no sub-adult male was trapped during the predawn capture in the wet season. Similar results were recently published by Noroalintseheno Lalarivoniaina et al. (2018) on the same colony of $R$.

Table 2. Retained Generalized Linear Model measuring the influence of each predictor (independent variable) on the dependent variables.

\begin{tabular}{llccc} 
Dependent variables & Predictors & Estimate & \multicolumn{1}{c}{$\boldsymbol{c}$} & $\boldsymbol{P}$ \\
Time of exit & (Intercept) & 1402000000.023 & 17.990 & $<\mathbf{0 . 0 0 1}$ \\
\cline { 2 - 5 } & Sub-adult female & 493.555 & 1.355 & 0.176 \\
\cline { 2 - 5 } & Sub-adult male & -288.598 & -0.780 & 0.436 \\
\hline Adult male & 121.923 & 4.239 & $<\mathbf{0 . 0 0 1}$ \\
\hline Time of return & 1180.012 & 1.187 & 0.236 \\
\cline { 2 - 5 } & BCI & 0.100 & 2.229 & $\mathbf{0 . 0 2 6}$ \\
\hline Time of return & (Intercept) & 1575000000.033 & 4698000.000 & $<\mathbf{0 . 0 0 1}$ \\
\cline { 2 - 5 } & Sub-adult female & -830.024 & -4.607 & $<\mathbf{0 . 0 0 1}$ \\
\cline { 2 - 5 } & Sub-adult male & 1657.001 & -8.763 & $<\mathbf{0 . 0 0 1}$ \\
\cline { 2 - 5 } & Adult male & 1258.012 & -8.232 & $<\mathbf{0 . 0 0 1}$ \\
\cline { 2 - 5 } & BCI & -796.111 & -1.733 & 0.084 \\
\cline { 2 - 5 } & Wet season & -5157.065 & -38.440 & $<\mathbf{0 . 0 0 1}$ \\
\hline
\end{tabular}

The influence of a predictor is significant when $P<0.050$ (in bold). BCI = body condition index. 
madagascariensis in the same cave and dispersal of sub-adult individuals in other diurnal roosts after the weaning period is suspected.

Aspects associated with moonlight were not analyzed in this study although light intensity can negatively affect nocturnal bat activity (Swift 1980; Elangovan and Marimuthu 2001; Thies et al. 2006; Appel et al. 2019). Bats are more detectable by nocturnal predatory birds when the light intensity is higher. Hence, further studies analyzing the effect of environmental parameters on bat emergence and early entry should consider details associated with moonlight and the ecology of bat predators. While this research project took place in a dry deciduous forest, a parallel study should also be carried out in the moist evergreen forests of eastern Madagascar in order to understand possible differences between these ecologically different habitats.

\section{Conclusions}

This study measured intraspecific variation of the nocturnal emergence of a tropical fruit bat and highlighted the relationship between emergence/return and energy demands, as well as seasonality of food resources. We demonstrated that the emergence time for $R$. madagascariensis varied according to the age and sex classes, and the time of return associated with the previous nocturnal activity; we showed the influence of season, and age and sex classes on time of return. This study provides the first precise data on the timing of emergence and return to a day roost site for Malagasy bats. Such information is important for providing baseline data to quantify the ecology of bat species, including in this case an endemic species playing an important role as seed dispersers and flower pollinators.

\section{Acknowledgements}

We thank our colleagues in the Mention Zoologie et Biodiversité Animale, Université d'Antananarivo; Madagascar National Parks (MNP); Direction de la Gestion des Ressources Naturelles Renouvelables et des Ecosystèmes; and the Direction Générale de l'Environnement et des Forêts for administrative support and permits to perform the fieldwork (permits no. 055/17/MEEF/SG/DGF/DSAP/SCB.Re and 265/17/MEEF/SG DGF/DSAP/SCB.Re). We acknowledge the Director of the Réserve Spéciale d'Ankarana for allowing us access to the Grotte des Chauves-souris. This project was funded by a grant from the Helmsley Charitable Trust to Association Vahatra. For their assistance in the field we are grateful to Léa Joffrin, Camille Lebarbenchon, Mbola T. P. Nekena, Jossah D. Randriamihaingo, and Romialy (Baban'i Rapila).

\section{Conflict of interest}

The authors declare no potential conflict of interest .

\section{Authors' contributions}

RVR and SMG conceived the study, performed the experiment, and wrote the manuscript. SMG supervised the fieldwork. RVR performed the data analysis. Both authors approved the final manuscript version. 


\section{References}

Acharya PR, Racey PA, McNeil D, Sotthibandhu S, Bumrungsri S. 2015. Timing of cave emergence and return in the dawn bat (Eonycteris spelaea, Chiroptera: Pteropodidae) in southern Thailand. Mammal Study. 40(1):47-52.

Altringham JD. 1996. Bats: Biology and behaviour. New York: Oxford University Press. 278 pp.

Andriafidison D, Andrianaivoarivelo RA, Ramilijaona OR, Razanahoera MR, MacKinnon J, Jenkins RKB, Racey PA. 2006. Nectarivory by endemic Malagasy fruit bats during the dry season. Biotropica. 38(1):85-90.

Andrianaivoarivelo RA. 2012. Écologie et population de Rousettus madagascariensis G. Grandidier, 1928 (Pteropodidae). Unpublished PhD Thesis. Universités de Rennes 1 et d'Antananarivo, Rennes. 162 pp.

Andrianaivoarivelo RA, Ramilijaona O, Racey PA, Razafindrakoto N, Jenkins RKB. 2011. Feeding ecology, habitat use and reproduction of Rousettus madagascariensis Grandidier, 1928 (Chiroptera: Pteropodidae) in eastern Madagascar. Mammalia. 75(1):69-78.

Anthony ELP. 1988. Age determination in bats. In: Kunz TH, editor. Ecological and behavioral methods for the study of bats. Washington, D.C.: Smithsonian Institution Press. p. 47-58.

Appel G, López-Baucells A, Magnusson WE, Bobrowiec PED. 2019. Temperature, rainfall, and moonlight intensity effects on activity of tropical insectivorous bats. Journal of Mammalogy. 100(6):1889-1900.

Bachorec E, Horáček I, Hulva P, Konečný A, Lučan RK, Jedlička P, Shohdi WM, Řeřucha Š, AbiSaid M, Bartonička T. 2020. Spatial networks differ when food supply changes: Foraging strategy of Egyptian fruit bats. PLoS ONE. 15(2):e0229110.

Balasingh J, Koilraj J, Kunz TH. 1995. Tent construction by the short-nosed fruit bat Cynopterus sphinx (Chiroptera: Pteropodidae) in southern India. Ethology. 100(3):210-229.

Barclay RMR, Jacobs DS. 2011. Differences in the foraging behaviour of male and female Egyptian fruit bats (Rousettus aegyptiacus). Canadian Journal of Zoology. 89(6):466-473.

Bullock DJ, Combes BA, Eales LA, Pritchard JS. 1987. Analysis of the timing and pattern of emergence of the pipistrelle bat (Pipistrellus pipistrettus). Journal of Zoology. 211(2):267-274.

Campbell P. 2008. The relationship between roosting ecology and degree of polygyny in haremforming bats: Perspectives from Cynopterus. Journal of Mammalogy. 89(6):1351-1360.

Cardiff SG, Befourouack J. 2008. La Réserve spéciale de 1'Ankarana. In: Goodman SM, editor. Paysage naturels et biodiversité de Madagascar. Paris: Publications scientifiques du Muséum. p. 571-584.

Cawten L. 2014. Anti-predation strategies of chocolate wattked bats (Chalinolobus morio) after a predation event at a maternal roost by a southern boobook (Tyto novaeseelandiae). The Tasmanian Naturalist. 136:35-42.

Chaverri G, Kunz TH. 2010. Ecological determinants of social systems: Perspectives on the functional role of roosting ecology in the social behavior of tent-roosting bats. In: Macedo R, editor. Advances in the study of behavior. Cambridge: Academic Press. p. 275-318. http://www.sciencedirect .com/science/article/pii/S0065345410420094

Desmarest A.-G. 1820. Mammalogie, ou, description des espèces de mammifères. Paris: Mme. Veuve Agasse, imprimeur-libraire. 584 pp. https://www.biodiversitylibrary.org/bibliography/59887

Dobson GE. 1871. Description of four new species of Malayan bats, from the collection of Dr. Stoliczka. The Journal of the Asiatic Society of Bengal. 40:260-267.

Downs CT, Zungu MM, Brown M. 2012. Seasonal effects on thermoregulatory abilities of the Wahlberg's epauletted fruit bat (Epomophorus wahlbergi) in KwaZulu-Natal, South Africa. Journal of Thermal Biology. 37(2):144-150.

Ebensperger LA, Hurtado MJ. 2005. Seasonal changes in the time budget of degus, Octodon degus. Behaviour. 142(1):91-112.

Elangovan V, Marimuthu G. 2001. Effect of moonlight on the foraging behaviour of a megachiropteran bat Cynopterus sphinx. Journal of Zoology. 253(3):347-350.

Erkert HG. 1978. Sunset-related timing of flight activity in Neotropical bats. Oecologia. 37(1):59-67. Erkert HG. 2000. Bats — Flying nocturnal mammals. In: Halle S, Stenseth NC, editors. Activity patterns 
in small mammals: An ecological approach. Berlin: Springer. p. 253-272. https://doi.org/ 10.1007/978-3-642-18264-8_16

Fenton MB, Fleming TH. 1976. Ecological interactions between bats and nocturnal birds. Biotropica. 8(2):104-110.

Fleming TH. 1979. Do tropical frugivores compete for food? American Zoologist. 19(4):1157-1172.

Fleming TH, Heithaus ER. 1981. Frugivorous bats, seed shadows, and the structure of tropical forests. Biotropica. 13(2):45-53.

Garbino GST, Rezende GC, Tavares VDC. 2018. Tent use by Artibeus and Uroderma (Chiroptera, Phyllostomidae) in northern Colombia. Mastozoologia Neotropical. 25(2):467-472.

García CB, García J, Martín MML, Salmerón R. 2015. Collinearity: Revisiting the variance inflation factor in ridge regression. Journal of Applied Statistics. 42(3):648-661.

Garg KM, Chattopadhyay B, Ramakrishnan U. 2018. Social structure of the harem-forming promiscuous fruit bat, Cynopterus sphinx, is the harem truly important? Royal Society Open Science. 5(2):172024.

Gehrt SD, Chelsvig JE. 2003. Bat activity in an urban landscape: Patterns at the landscape and microhabitat scale. In: Marzluff JM, Shulenberger E, Endlicher W, Alberti M, Bradley G, Ryan C, Simon U, ZumBrunnen C, editors. Urban ecology: An international perspective on the interaction between humans and nature. Boston, MA: Springer US. p. 437-453. https://doi.org/10.1007/9780-387-73412-5 29

Geoffroy ES-H. 1810. Description des roussettes et des céphalotes, deux nouveaux genres de la famille des chauves-souris. Annales du Muséum d'Histoire Naturelle. 15:86-108.

Geoffroy ES-H. 1824. La physiologie animale et végétale, l'anatomie comparée des deux règnes, la zoologie, la botanique, la minéralogie et la géologie. Annales des Sciences Naturelles. 1:342-343.

Gittleman JL, Thompson SD. 1988. Energy allocation in mammalian reproduction. American Zoologist. 28(3):863-875.

Gonsalves L, Bicknell B, Law B, Webb C, Monamy V. 2013. Mosquito consumption by insectivorous bats: does size matter? PLOS ONE. 8(10):e77183.

Goodman SM. 2011. Les chauves-souris de Madagascar. Antananarivo: Association Vahatra. 127 pp.

Goodman SM, Griffiths O. 2006. A case of exceptionally high predation levels of Rousettus madagascariensis by Tyto alba (Aves: Tytonidae) in western Madagascar. Acta Chiropterologica. 8(2):553-556.

Goodman SM, Raherilalao MJ, Wohlhauser S, editors. 2018. Les aires protégées terrestres de Madagascar : Leur histoire, description et biote / The terrestrial protected areas of Madagascar: Their history, description, and biota. Antananarivo: Association Vahatra. 1716 pp.

Goodman SM, Rajemison FI, Noroalintseheno Lalarivoniaina OS. 2017. Morphometric patterns of secondary sexual dimorphism and seasonal differences in Rousettus madagascariensis from northern Madagascar. Acta Chiropterologica. 19(1):71-75.

Goodman SM, Ramasindrazana B. 2018. Systématique des chauves-souris malgaches (ordre des Chiroptera) / Systematics of Malagasy bats (order Chiroptera). In: Goodman SM, Raherilalao MJ, Wohlhauser S, editors. Les aires protégées terrestres de Madagascar: Leur histoire, description et biote / The terrestrial protected areas of Madagascar: Their history, description, and biota. Antananarivo: Association Vahatra. p. 382-394.

Grandidier G. 1928. Description de deux nouveaux mammifères insectivores de Madagascar. Bulletin du Muséum national d'Histoire Naturelle. 34:63-70.

Gray JE. 1821. On the natural arrangement of vertebrose animals. London Medical Repository. 15(1):296-310.

Hodgkison R, Balding ST, Akbar Z, Kunz TH. 2003. Roosting ecology and social organization of the spotted-winged fruit bat, Balionycteris maculata (Chiroptera: Pteropodidae), in a Malaysian lowland dipterocarp forest. Journal of Tropical Ecology. 19(6):667-676.

Kimura K, Waki H. 2017. Minimization of Akaike's information criterion in linear regression analysis via mixed integer nonlinear program. Optimization Methods and Software. 33(3): 633-649.

Korine C, Arad Z. 1999. Changes in milk composition of the Egyptian Fruit Bat, Rousettus aegyptiacus (Pteropodidae), during lactation. Journal of Mammalogy. 80(1):53-59. 
Korine C, Izhaki I, Makin D. 1994. Population structure and emergence order in the fruit-bat (Rousettus aegyptiacus: Mammalia, Chiroptera). Journal of Zoology. 232(1):163-174.

Korine C, Zinder O, Arad Z. 1999. Diurnal and seasonal changes in blood composition of the freeliving Egyptian fruit bat (Rousettus aegyptiacus). Journal of Comparative Physiology B. 169(4):280-286.

Kunz TH. 1974. Feeding ecology of a temperate insectivorous bat (Myotis velifer). Ecology. 55(4):693-711.

Kunz TH, Anthony ELP. 1996. Variation in the timing of nightly emergence behavior in the little brown bat, Myotis lucifugus (Chiroptera: Vespertilionidae). In: Contributions in Mammalogy: A memorial volume honoring Dr J Knox Jones, Jr. Texas: Museum of Texas Tech University. p. $225-235$.

Lee YF, McCracken GF. 2001. Timing and variation in the emergence and return of Mexican freetailed Bats, Tadarida brasiliensis mexicana. Zoological Studies. 40(4):309-316.

Lučan RK, Bartonička T, Jedlička P, ̌̌eřucha Š, Šálek M, Č́ížek M, Nicolaou H, Horáček I. 2016. Spatial activity and feeding ecology of the endangered northern population of the Egyptian fruit bat (Rousettus aegyptiacus). Journal of Mammalogy. 97(3):815-822.

Maier C. 1992. Activity patterns of pipistrelle bats (Pipistrellus pipistrellus) in Oxfordshire. Journal of Zoology. 228(1):69-80.

Marimuthu G, Rajan KE, Koilraj AJ, Isaac SS, Balasingh J. 1998. Observations on the foraging behavior of a tent roosting megachiropteran bat Cynopterus sphinx. Biotropica. 30(2):321-324.

Matschie P. 1899. Die fledermäuse des Berliner Museums für Naturkunde, vol. 1: Die Megachiroptera des Berliner Museums für Naturkunde. Berlin: Berliner Museums für Naturkunde. 118 pp.

McAney CM, Fairley JS. 1988. Activity patterns of the lesser horseshoe bat Rhinolophus hipposideros at summer roosts. Journal of Zoology. 216(2):325-338.

Molina GI. 1782. Saggio sulla storia naturale del Chile. Bologna: Aquino. 368 pp.

Noroalintseheno Lalarivoniaina OS, Rajemison FI, Andrianarimisa A, Goodman SM. 2018. Variation saisonnière de la structure d'âge et de la sex-ratio de la population de Rousettus madagascariensis (Yinpterochiroptera : Pteropodidae) à Ankarana, nord de Madagascar. Revue d'Écologie (Terre et Vie). 73(1):23-30.

Noroalintseheno Lalarivoniaina OS, Rajemison FI, Goodman SM. 2017. Survie et variation temporelle de la taille de la population de Rousettus madagascariensis (Chiroptera: Pteropodidae) de la Grotte des Chauves-sours d'Ankarana, nord de Madagascar. Malagasy Nature. 12:68-77.

Olsson A, Emmett D, Henson D, Fanning E. 2006. Activity patterns and abundance of microchiropteran bats at a cave roost in south-west Madagascar. African Journal of Ecology. 44(3):401-403.

Ortega J, Arita HT. 2000. Defence of females by dominant males of Artibeus jamaicensis (Chiroptera: Phyllostomidae). Ethology. 106:395-407.

Ramanantsalama RV, Noroalintseheno Lalarivoniaina OS, Raselimanana AP, Goodman SM. 2019. Seasonal variation in diurnal cave-roosting behavior of a Malagasy fruit bat (Rousettus madagascariensis, Chiroptera: Pteropodidae). Acta Chiropterologica. 21(1):115-127.

Ramanantsalama RV, Noroalintseheno Lalarivoniaina OS, Raselimanana AP, Goodman SM. (in preparation). Influence of environmental parameters on the breeding of an endemic Malagasy fruit bat, Rousettus madagascariensis (Pteropodidae). Acta Chiropterologica.

Reher S, Ehlers J, Rabarison H, Dausmann KH. 2018. Short and hyperthermic torpor responses in the Malagasy bat Macronycteris commersoni reveal a broader hypometabolic scope in heterotherms. Journal of Comparative Physiology B. 188(6):1015-1027.

Ripperger SP, Kalko EKV, Rodríguez-Herrera B, Mayer F, Tschapka M. 2015. Frugivorous bats maintain functional habitat connectivity in agricultural landscapes but rely strongly on natural forest fragments. PLoS One. 10(4). e0120535. https:/www.ncbi.nlm.nih.gov/pmc/articles/PMC4382216/

Roy K, Saha GK, Mazumdar S. 2020. Seasonal influence on the diurnal roosting behaviour of freeranging Indian flying fox Pteropus giganteus in an urban landscape, India. Biologia. https://doi.org/10.2478/s11756-020-00472-4

Rydell J, Speakman JR. 1995. Evolution of nocturnality in bats: Potential competitors and predators during their early history. Biological Journal of the Linnean Society. 54(2):183-191. 
Schreber JCD. 1774. Die Säugthiere in Abbildungen nach der Natur, mit Beschreibungen. Erlangen: Expedition des Schreber'schen säugthier- und des Esper'schen Schmetterlingswerkes. 544 pp. https://www.biodiversitylibrary.org/bibliography/67399

Scopoli GA. 1769. Anni Historico-Naturales. Leipzig: Library New York Botanical Garden. 151 pp. Speakman JR. 1995. Chiropteran nocturnality. Symposia of the Zoological Society of London. 67:187-201.

Speakman JR, Racey PA. 1986. The influence of body condition on sexual development of male brown long-eared bats (Plecotus auritus) in the wild. Journal of Zoology. 210(4):515-525.

Speakman JR, Hays GC, Webb PI. 1994. Is hyperthermia a constraint on the diurnal activity of bats? Journal of Theoretical Biology. 171(3):325-339.

Stribna T, Romportl D, Demjanovič J, Vogeler A, Tschapka M, Benda P, Horáček I, Juste J, Goodman SM, Hulva P. 2019. Pan African phylogeography and palaeodistribution of rousettine fruit bats: Ecogeographic correlation with Pleistocene climate vegetation cycles. Journal of Biogeography. 46(10):2336-2349.

Sugiura N. 1978. Further analysis of the data by Akaike's information criterion and the finite corrections. Communications in Statistics - Theory and Methods. 7(1):13-26.

Swift SM. 1980. Activity patterns of pipistrelle bats (Pipistrellus pipistrellus) in north-east Scotland. Journal of Zoology. 190(3):285-295.

Thies W, Kalko EKV, Schnitzler H-U. 2006. Influence of environment and resource availability on activity patterns of Carollia castanea (Phyllostomidae) in Panama. Journal of Mammalogy. 87(2):331-338.

Thomas SP, Follette DB, Farabaugh AT. 1991. Influence of air temperature on ventilation rates and thermoregulation of a flying bat. American Journal of Physiology. 260(5):960-968.

Vahl M. 1797. Beskrivelse pa tre nye arter flagermuse. Skrifter Naturhistorie-Selskabet Copenhagen. 4:121-138.

Vanlalnghaka C, Joshi DS. 2005. Entrainment by different environmental stimuli in the frugivorous bats from the Lonar Crater. Biological Rhythm Research. 36(5):445-452.

Vanlalnghaka C, Keny VL, Satralkar MK, Pujari PD, Joshi DS. 2005. Social entrainment in the old frugivorous bats, Rousettus leschenaulti from the Lonar Crater. Biological Rhythm Research. 36(5):453-461.

Venables LSV. 1943. Observations at a pipistrelle bat roost. Journal of Animal Ecology. 12(1):19-26.

Voigt CC, Lewanzik D. 2011. Trapped in the darkness of the night: Thermal and energetic constraints of daylight flight in bats. Proceedings of the Royal Society B. 278(1716):2311-2317.

Vololona J. 2020. Etude des interactions entre Rousettus madagascariensis G. Grandidier, 1928 (Chiroptera: Pteropodidae) et les plantes à fleurs de la Réserve Spéciale d'Ankarana, Nord de Madagascar. Approche palynologique. Unpublished PhD Thesis. Antananarivo: Université d'Antananarivo. 226 pp.

Vololona J, Ramavovololona P, Noroalintseheno Lalarivoniaina OS, Goodman SM. 2020. Fleurs visitées par Rousettus madagascariensis G. Grandidier, 1928 (Chiroptera : Pteropodidae) dans la Réserve Spéciale d'Ankarana, Madagascar. Bulletin de la Société Zoologique de France. 145(1):49-67.

Wakefield A, Stone EL, Jones G, Harris S. 2015. Light-emitting diode street lights reduce last-ditch evasive manoeuvres by moths to bat echolocation calls. Royal Society Open Science. 2(8):150291.

This article is distributed under the terms of the Creative Commons Attribution Noncommercial License (by-nc 4.0) which permits any noncommercial use, distribution, and reproduction in any medium, provided the original author(s) and source are credited. 